OPEN ACCESS

Edited by:

Leslie Cornick

Eastern Washington University,

United States

Reviewed by:

Henry P. Huntington,

Independent Researcher,

United States

William Gerald Ambrose Jr.

Bates College, United States

${ }^{*}$ Correspondence: Kristin L. Laidre klaidre@uw.edu

Specialty section:

This article was submitted to Global Change and the Future Ocean,

a section of the journal Frontiers in Marine Science

Received: 14 January 2018 Accepted: 05 April 2018

Published: 11 May 2018

Citation:

Laidre KL, Northey $A D$ and Ugarte F (2018) Traditional Knowledge About Polar Bears (Ursus maritimus) in East Greenland: Changes in the Catch and

Climate Over Two Decades.

Front. Mar. Sci. 5:135.

doi: 10.3389/fmars.2018.00135

\section{Traditional Knowledge About Polar Bears (Ursus maritimus) in East Greenland: Changes in the Catch and Climate Over Two Decades}

\author{
Kristin L. Laidre ${ }^{1 *}$, Allison D. Northey ${ }^{1}$ and Fernando Ugarte ${ }^{2}$ \\ ${ }^{1}$ Applied Physics Laboratory, Polar Science Center, University of Washington, Seattle, WA, United States, ${ }^{2}$ Department of \\ Birds and Mammals, Greenland Institute of Natural Resources, Nuuk, Greenland
}

In Greenland, polar bears (Ursus maritimus) are nutritional, economic, and cultural subsistence resources for Inuit. Traditional Ecological Knowledge (TEK) collected from subsistence hunters can provide important insights and improve management decisions when collected systematically. We report on the results of a TEK survey of subsistence polar bear hunters living in the areas around Tasiilaq and Ittoqqortoormiit, East Greenland. Twenty-five full-time polar bear hunters were interviewed between December 2014 and March 2015 in a conversation-style interview, where a local interviewer fluent in the East Greenlandic dialect asked a series of 55 predetermined questions. The primary goals were to (1) gather Inuit perspectives on polar bear subsistence quotas and hunting strategies, (2) understand how climate change is affecting the polar bear subsistence hunt, and (3) document observed changes in polar bear distribution, abundance, and biology. Approximately 40\% of the Tasiilaq respondents had caught between 10 and 19 polar bears in their lifetime, while $67 \%$ of Ittoqqortoormiit respondents reported lifetime catches of $\geq 20$ bears. In both areas, polar bears were most commonly hunted between February and April. Hunters noted large changes to the climate in the areas where they hunt polar bears. Most hunters reported loss of sea ice, receding glaciers, unstable weather, and warmer temperatures. In Tasiilaq $73 \%$ of the hunters said climate changes had affected the polar bear hunt and in Ittoqqortoormiit about $88 \%$ of respondents reported the same. Hunters indicated that sea ice loss has created more areas of open water so dog sledges have become unsafe for hunting transportation compared to 1015 years ago (reported by $100 \%$ of hunters in Tasiilaq and $80 \%$ in Ittoqqortoormiit). In Ittoqqortoormiit, the distance traveled during polar bear hunting trips has decreased dramatically. In both areas hunters noted that more polar bears are coming into their communities compared to $10-15$ years ago (81\% of Tasilaq hunters and $78 \%$ of Ittoqqortoormiit hunters) and pointed to the introduction of quotas and loss of sea ice as potential reasons. This study provides an important perspective on the East Greenland subpopulation of polar bears that can be used to direct science questions and inform management.

Keywords: Arctic, Greenland, polar bear, Ursus maritimus, subsistence, traditional ecological knowledge, TEK 


\section{INTRODUCTION}

Across Greenland, polar bears (Ursus maritimus) are nutritionally, economically, and culturally important and valuable as subsistence resources. Inuit hunters traditionally harvest polar bears as a source of sustenance, clothing, and tools (Born et al., 2011). Towns and settlements may also be economically supported by selling polar bear skulls, claws, or skins. In addition, the polar bear is valued culturally as a symbol to the traditional hunting community and provides a sense of identity for the individuals therein (Born et al., 2011). Inuit hunters have a strong understanding of the Arctic environment and assimilate information from older generations and personal experience (Born et al., 2011; Wong et al., 2011; Voorhees et al., 2014) which is valuable to management and conservation.

Traditional Ecological Knowledge (hereafter TEK) refers to knowledge acquired by indigenous and local peoples over hundreds or thousands of years through direct contact with the environment. Arctic TEK studies have unearthed a myriad of ecological information from Inuit hunters on topics such as polar bear denning, Arctic caribou (Rangifer) population assessments, spatial patterns of beluga whales (Delphinapterus leucas), and broad effects of changing sea ice on marine mammals (Ferguson and Messier, 1997; Van de Velde et al., 2003; Lewis et al., 2009; Fidel et al., 2014; Voorhees et al., 2014; Huntington et al., 2016). This methodology can be used together with scientific ecological knowledge (i.e., western science) to broaden the scope of research findings (Ambrose et al., 2014). Vongraven et al. (2012) noted the need for using TEK in conjunction with western science to advise management and conservation decisions on polar bears. However, for TEK to be used in this context, it should be collected through systematic surveys and summarized in meaningful ways. Polar bear TEK surveys have been conducted extensively in West Greenland through interviews of over 60 hunters in all municipalities (Born et al., 2011). However, in East Greenland TEK on polar bears has not been collected for almost two decades (Sandell and Sandell, 1996; Dietz et al., 2001; Sandell et al., 2001; Rosing-Asvid, 2002). Thus, current perspectives of hunters in this area are largely undocumented.

The East Greenland (EG) polar bear subpopulation ranges over one of the largest geographic areas (Laidre et al., 2015) of the 19 recognized subpopulations across the circumpolar Arctic. The range covers the annual and offshore multi-year pack ice along the entire Greenland coast between $60^{\circ} \mathrm{N}$ and $80^{\circ} \mathrm{N}$ including Fram Strait, the Greenland Sea, and the Denmark Strait (Figure 1). The size of the EG subpopulation is unknown (Obbard et al., 2010) and satellite tracking studies in NE Greenland indicate limited exchange with other subpopulations nearby (Wiig, 1995; Paetkau et al., 1999).

There are three areas where occupational subsistence hunters harvest polar bears from the EG polar bear subpopulation under a quota management system: Tasiilaq, Ittoqqortoormiit, and communities in South Greenland (i.e., the southernmost part of west Greenland, Figure 1). Quotas were established across Greenland in 2006. At the time there was no scientific assessment of the EG subpopulation, so the Greenland government selected a quota that was equal to the average catches from 2000 to 2004
(20 polar bears per year for Tasiilaq, 30 for Ittoqqortoormiit, and 4 for South Greenland). Due to community requests, this quota was raised in 2007 to 25 polar bears per year in Tasiilaq, 35 in Ittoqqortoormiit, and 4 in South Greenland. We focused our study on the two areas with the largest numbers of active polar bear hunters: Tasiilaq and Ittoqqortoormiit.

Projected decrease in sea ice due to climate change threatens the hunting platform from which polar bears catch ringed seals (Pusa hispida), their preferred prey (Regehr et al., 2016). Similarly, Inuit hunters rely on the same sea ice platform for spring hunting access to polar bears. In East Greenland, loss of sea ice over the past several decades has been substantial, with the sea ice season shortening at a rate of 10.6 days per decade (Laidre et al., 2015; Stern and Laidre, 2016). Understanding the impact of decreased sea ice extent on polar bear condition, abundance and distribution is essential for their conservation and management. However, at the same time, it is important for management to understand the impact of sea ice loss on subsistence catches (e.g., Huntington et al., 2017) and the human communities that rely on polar bears as a resource. Our primary goal was to gather perspectives from active Inuit polar bear hunters on EG quotas, hunting strategies, and how climate change may be affecting the environment, polar bear distribution, abundance, and biology through time.

\section{MATERIALS AND METHODS}

\section{Study Area}

The area of Tasiilaq is comprised of five settlements around the town of Tasilaq, situated at approximately $65^{\circ} \mathrm{N}$ in the sub-Arctic near the Sermilik fjord. Ittoqqortoormiit is located in the high Arctic at the northern entrance of the Scoresby Sound/Kangersuttaq fjord at $70.5^{\circ} \mathrm{N}, 900 \mathrm{~km}$ north of Tasiilaq. The two areas are separated by a large expanse of uninhabited coastline where there is limited travel by humans between communities. Both areas have annual sea ice cover in winter and spring however conditions slightly differ. Most of the area around Ittoqqortoormiit is covered by sea ice throughout the year due to large amounts of multi-year sea ice transported south through Fram Strait. Around Tasilaq the sea ice is present in spring in lower concentrations and melts out annually by summer.

\section{Preparation and Selection of Informants}

Before the start of the interviews, residents of Tasiilaq and Ittoqqortoormiit were informed about the background and purpose of the study. Information regarding the study was sent by letter to inform the Organization of Fishermen and Hunters in Greenland (KNAPK) and letters were displayed on the local bulletin boards with the help of KNAPK local branches. A press release about the study was issued and broadcast on national TV, radio, and newspaper.

The choice of which settlements to visit and the selection of interviewees were based upon catch records for each hunter as reported to the Department of Fisheries, Hunting and Agriculture (the Greenland Government, Nuuk). We ensured 


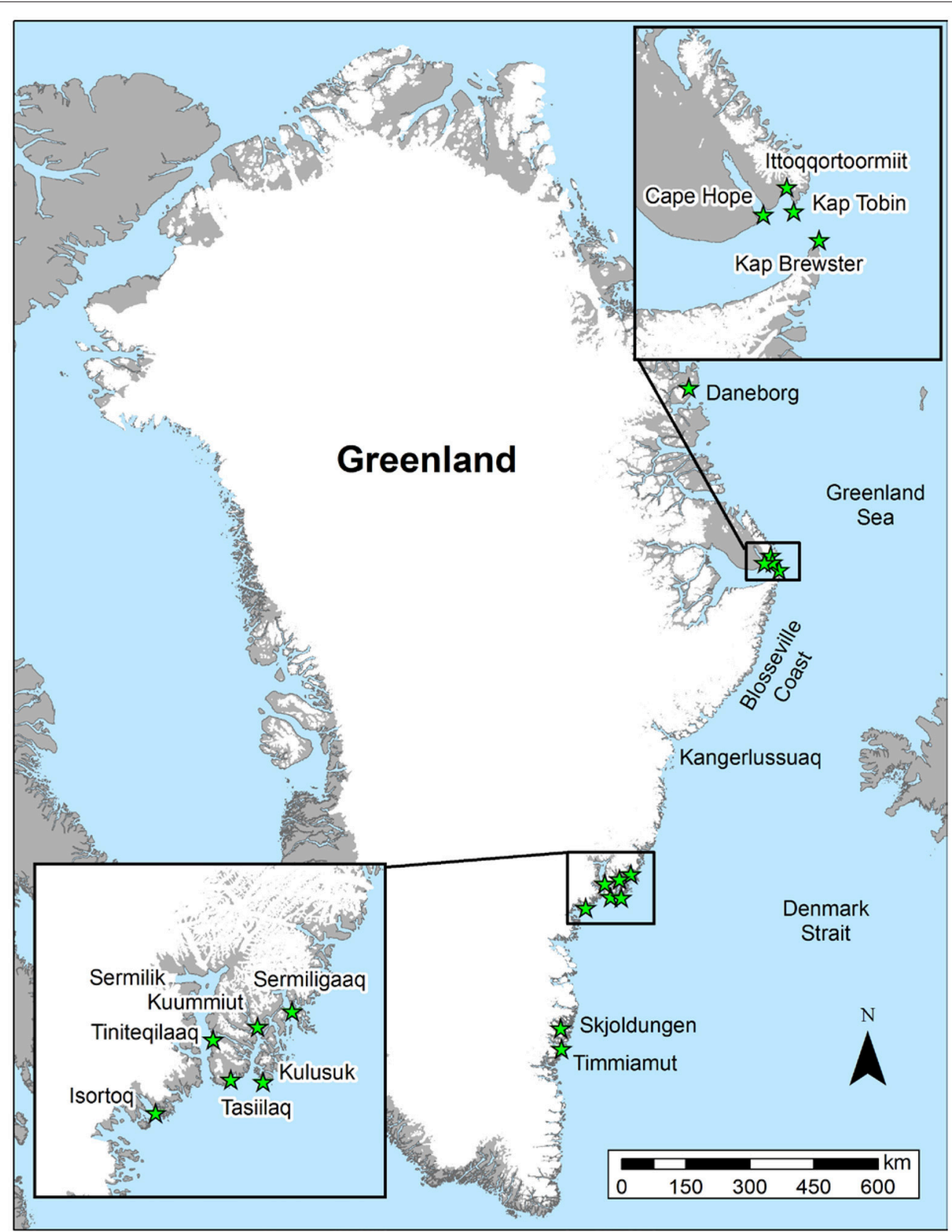

FIGURE 1 | Map of the study area in East Greenland, including settlements and major localities discussed in the text.

that we were interviewing hunters with recent knowledge about polar bear hunting based on government catch reports, and selected hunters that had taken $>3$ polar bears between 2009 and 2013 in Tasiilaq, and $>5$ polar bears during the same period in Ittoqqortoormiit. The threshold was lower in Tasiilaq because there was a larger number of hunters taking fewer polar bears annually. In total, we interviewed 16 hunters in Tasiilaq and 9 hunters in Ittoqqortoormiit. Polar bear hunting is historically a male-dominated activity, thus all interviewees were men ranging from 20 to 64 years of age.

\section{The Form and Content of the Interviews}

Interviews were carried out between December 2014 and March 2015 in Greenlandic, where a local interviewer asked a series of 55 predetermined questions (Supplemental Material). Key topics and questions were chosen and developed by scientists involved in the study and were based on work conducted by Born et al. (2011). Individual hunters chose their preferred interview setting; most interviews were conducted in the privacy of the hunter's home. Only one hunter was interviewed at a time. Interviews were recorded on digital dictaphones and typically lasted $2 \mathrm{~h}$, 
although occasionally varied in duration. Hunters were given a variety of different map options and colored pens with which they could illustrate their responses to questions outlining locations of hunting routes, polar bear habitat, maternity dens, or areas where they observed changes in the physical environment. Hunters could use more than one map for a single question if needed, or provide their answers to multiple questions on one map.

Interviews used the set questionnaire that acted as a guide for conversational interaction (Huntington, 1998). Hunters were allowed to speak freely about any other topics at any point in the interview to allow the interviewee to raise topics or connections unforeseen by the researchers when selecting questions. Interviews were designed to extract a variety of TEK, from individual experience to information passed down through generations. Hunters were promised anonymity in the study. Each hunter received approximately \$120 USD for their time, which was considered to be the standard compensation rate for lost earnings given the hunters were asked to stay at home to be interviewed when they could have been out hunting.

The interviews in Tasiilaq were carried out during December and January, the months of darkness after the boating season is over and before the sea ice is solid enough for hunting trips by sledge dog. This period was selected because there was a higher chance of finding a hunter at home. This was important in Tasiilaq because the interviewer had to reach five different settlements by helicopter to carry out the interviews. In Ittoqqortoormiit, the interviewer and the hunters lived in the same settlement, so the timing of the interviews was less crucial and the interviews were conducted between December and March.

The Government of Greenland, under whose auspices this research was conducted, does not have an Institutional Review Board (IRB) human subjects committee nor a requirement for such review. In the absence of ethical guidelines for TEK studies in Greenland, we followed the relevant aspects of the guidelines for medical research with human subjects issued by the Health Authority of Greenland (http://nun.gl/Videnskabsetiskselvdeklaration/42 and http://nun.gl), in that the study goals, type of questions, and degree of anonymity were clearly explained prior to the interview. Prior to the fieldwork, the research project was presented to and approved by the KNAPK. Free, prior, and informed consent was obtained from all individuals who were interviewed. Participants were aware that they could decline to be interviewed, could stop the interview at any time, and could refuse to answer any question. They were also informed that refusal to participate would not affect their relationship with the government. Participants agreed the information could be published in an anonymized form in scientific literature and disseminated through the Greenlandic media. This study did not meet the criteria for University of Washington IRB.

\section{Analysis of the Data}

Recorded interviews were translated and transcribed from Greenlandic to English and all written survey material was scanned. Hunters were assigned unique ID numbers (1-16 for Tasiilaq hunters, 17-25 for Ittoqqortoormiit hunters) to maintain anonymity and for ease of organizing answers. A database was synthesized to organize hunters' responses by question and municipality, and tables or graphs were created for each question to display responses visually. A second database was created to summarize and establish general trends and common categories of responses given by hunters within each question for each municipality. For example, for a question that allowed the hunter to give a free response (i.e., not a categorical question), responses were manually grouped into reoccurring themes such as "glaciers are disappearing," or "more snow." Since each hunter could choose not to answer a question, some results are reported for a smaller subset of hunters $(<16$ in Tasiilaq and $<9$ in Ittoqqortoormiit) and in this case we state the sample size for that question in the results. In a few cases hunters had answers that could not be interpreted and these were excluded.

We used ESRI ArcGIS 10.2 to scan, code and digitize a total of 138 maps from hunters that were created during the interview process (103 maps from Tasiilaq hunters, 35 maps from Ittoqqortoormiit hunters) and consolidated answers onto a single map per question per municipality. Data were constructed using point, line, and polygon feature classes. Attribute tables were added with each map to reflect metadata.

\section{Time Periods}

Many survey questions were designed to gather TEK during two time periods in order to compare 'present conditions' (e.g., 2012-2014) to conditions that occurred 10-15 years ago. Data represented therefore describe the period between 2000 and 2005 ("past") and the 5-year period around the interviews, 2010-2015 ("present") unless otherwise stated by the hunter. For certain aspects of the study, mainly in map questions, the year was divided into three-month increments, which roughly line up with seasons as follows: winter (January-March), spring (April-June), summer (July-September), and autumn (OctoberDecember). Seasons were displayed through different colors to visually organize the data temporally.

\section{Population Statistics}

Data on the number of full-time and part-time (leisure) hunters for the different regions of Greenland were obtained from the Department of Fisheries and hunting. Data on settlement population size was accessed online from the Statbank, Greenland, from Statistics Greenland (www.stat.gl).

\section{RESULTS}

In Tasiilaq, the population size has remained generally stable since 1996 at about 3,000 people. However the number of registered full-time hunters has sharply declined from 231 in 1996 to 68 in 2016. In Ittoqqortoormiit, the population size and number of full-time hunters has declined slowly and steadily, with the population size declining from 506 in 1996 to 389 in 2016 and the number of full-time hunters declining from 41 to 12 over that same period. Beginning in 2006, only full-time hunters were allowed to catch polar bears.

In Tasiilaq, the age of interviewed hunters ranged from 32 to 64 years $($ mean $=46$, sd $=9.1, n=16$ ). Half of the Tasiilaq respondents were between 40 and 49 . Ittoqqortoormiit 
respondents were aged between 20 and 58 years (mean $=40$, $\mathrm{sd}=15.45, n=9)$. Three of these hunters were in their twenties, and just under half (ca. 44\%) were between 50 and 59. About $64 \%(n=9)$ of the 14 Tasiilaq hunters were between 15 and 20 years old when they participated in their first polar bear hunt and they caught their first polar bear between the ages of 11 and 38 (mean $=23$, sd $=7.38)$. The majority $(\mathrm{ca} .83 \%, n=5)$ of Ittoqqortoormiit hunters said they were between 14 and 18 years old (mean $=17$, sd $=1.96$ ) on their first polar bear hunt, and caught their first polar bear between 14 to 20 years old (mean $=17, \mathrm{sd}=2.12, n=7)$. Mean ages are rounded to nearest integer.

\section{The Catch of Polar Bears and Hunting Strategies}

Of the 16 Tasiilaq hunters, $50 \%$ said that they hunt polar bears $>5$ times per year. The remaining informants hunted less frequently, although no hunters answered that they hunt less than once per year. Half of the eight Ittoqqortoormiit respondents said they hunt three to five times per year, followed by one hunter who hunts less frequently and three hunters who said they hunt $>5$ times per year. All hunters in both places noted that they do not go hunting only for polar bears, but at the same time hunt for other species such as seals or narwhals (Monodon monoceros). Most hunting of polar bears in East Greenland occurs from winter (January) through spring (May). Some hunters mentioned they used to hunt in July however due to sea ice loss it is no longer possible to go during that month with a dog sledge. Others mentioned the hunt starts earlier now. It was unclear if this was because there are more polar bears closer to town (so that they can be taken without waiting for maximum sea ice extent in spring).

Hunters reported what they do with specific parts of the polar bear, including the skin, cranium, claws, and meat. Of 12 hunters from Tasiilaq who responded, 100\% reported that they sell the skin for 5000-20000 Danish kroner (DKK, 800-3,200 USD assuming $6.3 \mathrm{DKK}: 1 \mathrm{USD}$ ), noting that the price depends on the size of the skin. One hunter said he will sell the cranium for 20003000 DKK ( 300-500 USD) when someone asks, however noted it was uncommon. In Ittoqqortoormiit $100 \%$ of respondents said that they sell the skin and cranium to private buyers and over half of these hunters sell the skin and skull together. The economic value of the skin ranged from 6000 to 18000 DKK $(\sim 1,000-2,900$ USD). The value of the cranium as reported by $n=7$ hunters was 1000-2000 DKK ( 150-300 USD). Claws are sold for 100200 DKK ( 16-32 USD) per claw in both areas. No respondents provided the economic value of polar bear meat in Tasiilaq but noted it is occasionally sold. In Ittoqqortoormiit the economic value of the meat was $85 \mathrm{DKK}(\sim 13 \mathrm{USD})$ per $\mathrm{kg}$.

\section{Numbers and Categories of Polar Bears Caught}

Each hunter was asked about his catches during 2012, 2013, and 2014. Total catch across these years was calculated for each hunter then averaged across all hunters in each area. During 2012, 2013, and 2014 Tasiilaq hunters caught an average of 2.7 polar bears each (range $1-7$ bears, sd $=1.7$ bears). Ittoqqortoormiit responses were highly variable with an average of 10.3 bears and a range of $1-24$ bears ( $\mathrm{sd}=7.1$ ). Of 15 Tasiilaq hunters who responded to this question, all but one said they had reported all catches to the authorities. All of the nine Ittoqqortoormiit hunters said they reported every catch to the authorities.

Approximately $40 \%(n=6)$ of 15 Tasiilaq hunters estimated they had caught between 10 and 19 polar bears in their lifetime, followed by $33 \%(n=5)$ who reported catching $1-9$ polar bears in their lifetime, and the remaining $27 \%(n=4)$ said they had caught 20 or more polar bears in their life. The majority $(67 \%$, $n=6$ ) of Ittoqqortoormiit hunters reported lifetime catches of 20 or more polar bears. The remaining $33 \%$ of hunters in this area responded with catch values between 10 and 19 polar bears.

In Tasiilaq, $47 \%$ of the respondents said their catch levels were the same as 10-15 years ago, while a few hunters noted that they catch more or fewer than they used to (Table 1). Many hunters said the quotas influenced the number of polar bears they catch; the quota may be filled quickly limiting the number of polar bears an individual hunter can catch. Some also suggested that if the quota was larger they would be able to catch more polar bears. Half the hunters from Ittoqqortoormiit reported that they catch more polar bears than 10-15 years ago and 38\% said it was the same (Table 1). A few noted the conditions vary from year to year and the ice conditions determine whether they catch a polar bear in a given year. One hunter noted that he has caught more polar bears recently because there are more polar bears near town. Some hunters said they catch more polar bears now because it is illegal to hunt females with cubs allowing the population size to increase and therefore more polar bears are caught in their settlement. Some hunters were of the opinion that more polar bears are caught in their settlement nowadays because receding sea ice has forced more polar bears on land and in town. Hunters in both areas largely reported that they catch both male and female polar bears in similar numbers, and that they catch whatever polar bear they see regardless of the sex. Some noted they cannot tell the sex of the polar bear until they shoot it.

Among Tasiilaq hunters, $81 \%(n=13)$ said they catch what they see and do not target a specific sex, age, or size of bear. Some hunters explained they have less flexibility to be selective toward a specific group of polar bears because of the quota (authors' note: quotas are not age or sex specific, only females with cubs are

TABLE 1 | Distribution of responses to question 11: "Do you catch more bears than you used to compared to $10-15$ years ago?"

\begin{tabular}{lcc}
\hline & Tasiilaq & Ittoqqortoormiit \\
\hline More & $27 \%(4)$ & $50 \%(4)$ \\
Less & $20 \%(3)$ & $12 \%(1)$ \\
Same & $47 \%(7)$ & $38 \%(3)$ \\
Don't know & $7 \%(1)$ & - \\
\hline
\end{tabular}

$\mathrm{N}_{\text {total }}$ (hunters asked) 15 8

Number in parentheses corresponds to the number of hunters who selected each response. Percentages are rounded to nearest integer. See Supplemental Material for full list of interview questions. 
protected). About $67 \%$ of the nine Ittoqqortoormiit respondents said that they target large polar bears. One of these hunters said that he makes more money from selling the skin of larger polar bears and the remaining hunters said they catch what they see.

The general consensus among 15 hunters from Tasiilaq (87\%, $n=13$ ) was that the quotas for the polar bear harvest are necessary. Of the two (13\%) hunters who were of the opinion that quotas are unnecessary, one hunter mentioned a surplus of polar bears and said that there are still many polar bears around when the quotas are used up. Conversely, the general consensus among eight hunters from Ittoqqortoormiit was that quotas are unnecessary $(63 \%, n=5)$. The remaining three hunters $(37 \%)$ said that quotas are necessary, though there were additional remarks saying that the quotas are too low.

In Tasiilaq, $75 \%(n=12)$ of the hunters said that there have been more polar bears coming into town since the quotas were established and that this occurs primarily when the quota is used up. Hunters in Tasiilaq noted differences between their community and Ittoqqortoormiit, specifically that there are some part-time hunters taking polar bears which reduces the number of polar bears available for the full-time hunters (authors' note: it is illegal for part-time hunters to catch polar bears and licenses are given exclusively to full-time hunters). They noted that in far SE Greenland, e.g., Skjoldungen and Timmiamiut, there are many polar bears. In Tasiilaq some hunters said that the cultural rules around who gets the skin (the first person to see the bear, not the person to shoot it) reduces the number of polar bears they can obtain in a season. Therefore, many hunters go out hunting alone or go out only with their family to ensure the skin of the polar bear stays within the family. In Ittoqqortoormiit, roughly $38 \%(n=3)$ of the eight respondents did not report any effects from quotas, another $38 \%(n=3)$ said that there are more polar bears around because of the quotas, and two hunters (25\%) mentioned that they caught fewer polar bears after the quotas were introduced. In both areas, there were mixed responses when hunters were asked if they catch more or less polar bears due to the quota. In both areas roughly $30-40 \%$ of the hunters said they catch fewer polar bears, 35\% said the same number, and 25\% said they catch more.

In Tasiilaq, $69 \%$ of the hunters $(n=11)$ suggested that there may be ways to improve regulation of hunt. All of these hunters mentioned that there should be a wildlife officer (authors' note: a government officer in town, called "jagtbetjent" in Danish, that monitors the hunt, fisheries and any illegal activity related to fisheries and hunting). In Ittoqqortoormiit, 50\% of eight respondents noted there could be ways to improve regulation of the hunt, with a few who said a wildlife officer could be useful (authors' note: there are 12 wildlife officers spread over Greenland, there has been one in Ittoqqortoormiit since 2009, but none in Tasiilaq). Some hunters expressed frustration with other hunters using snowmobiles to hunt (authors' note: this is illegal) and a wildlife officer may keep the hunters who are illegally hunting from snowmobiles in check. Hunters in both places were generally supportive of allocating part of the quota to sports hunting. $75 \%$ of Tasiilaq respondents and $100 \%$ of Ittoqqortoormiit respondents said sport hunting would increase revenue and allow hunters a better living.

\section{Hunting Methods}

In Tasiilaq, most hunters identified February (ca. $88 \%$ of all hunters, $n=14$ ), March (94\%, $n=15$ ), and April (ca. $88 \%$, $n=14$ ) as the best months to hunt polar bears (Figure 2A). Nine Ittoqqortoormiit hunters also noted the same months, February $(100 \%, n=9)$, March $(100 \%, n=9)$, and April (ca. $88 \%, n=8)$ (Figure 2B). Hunters mentioned weather and sea ice conditions as the reason these were the best months, in addition to higher densities of polar bears or the skin being in the best condition. Many hunters also said this is the period when the sea ice forms.

In both areas, roughly 55-65\% of the hunters answered that the best time to catch polar bears has changed in the last 10 to 15 years (Table 2). Most hunters said that the sea ice is forming later in the winter and many fjords are ice-free now. Some hunters noted that the ice may form but it disappears quickly or is unsafe. A 45-year-old hunter described climatic and weather changes in Greenland and said "the ozone layer is getting thinner, the weather is getting warmer and changing [...] and other countries cause greenhouse gas emissions." A few hunters mentioned the quotas and discussed how they used to hunt in summer months but that this is no longer allowed.

Hunters in Tasiilaq were asked what their main mode of transportation was for hunting polar bears. About $44 \%(n=7)$ said dog sledge while another $44 \%(n=7)$ answered both dog
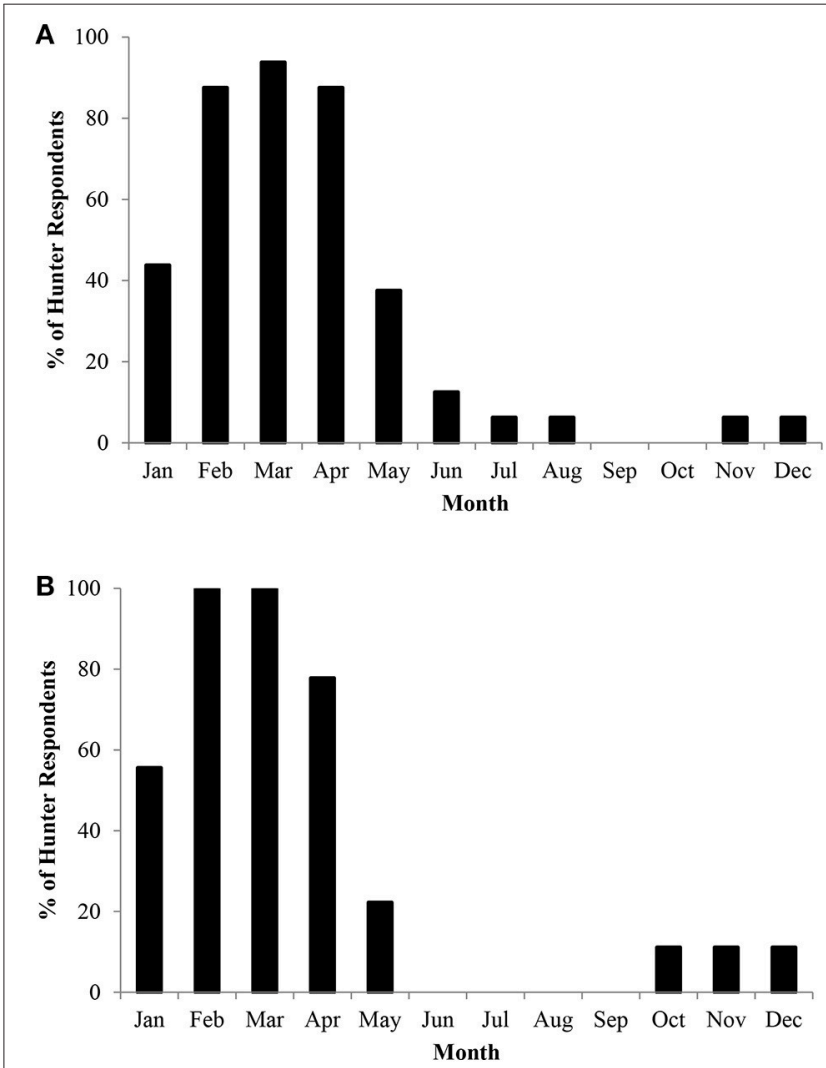

FIGURE 2 | (A,B) Distribution of months selected by (A) Tasillaq hunters $(n=16)$ and $\mathbf{( B )}$ Ittoqqortoormit hunters $(n=9)$ in response to "When is the best time to hunt polar bears nowadays?" 
sledge and boat (Table 3). Only about $12 \%(n=2)$ of Tasiilaq hunters said that they solely use boat. An experienced 51-yearold hunter said he uses both means of transport and that he will usually put his boat on his sledge. Among the Ittoqqortoormiit hunters, nearly $78 \%$ responded that they use a dog sledge, and the remaining $22 \%(n=2)$ said that they use both sledge and boat (Table 3). No hunters answered that they solely use boat.

All hunters $(100 \%, n=15)$ in Tasiilaq noted that they now hunt more with a boat and less with a dog sledge than 10-15 years ago. Most responses $(75 \%, n=12)$ explained that this was due to changes in sea ice. Hunters indicated that ice retreat has exposed more areas of open water so they use boats because sledges are unsafe. One informant explained that he had gotten rid of his sled dogs because the lack of sea ice meant there was no longer a reason for him to own a sledge. Approximately $80 \%$ of five Ittoqqortoormiit respondents noted they use a boat more than $10-15$ years ago, while a single (20\%) hunter uses a sledge more. These hunters also spoke of how there is less sea ice and it is forming later. Two hunters also mentioned using snowmobiles (authors' note: illegal for hunting polar bears). A 56-year-old hunter spoke of a recent decrease in his use of dog sledges when hunting, and said "the sledge season is so short now, they begin so

TABLE 2 | Types of responses to question 25: "Has the best time to hunt polar bears changed during the last 10-15 years?", and reasons given for question 25a: "why?"

\begin{tabular}{lcc}
\hline & Tasiilaq & Ittoqqortoormiit \\
\hline Changed & $63 \%(10)$ & $56 \%(5)$ \\
- weather/ice changes & 6 & 5 \\
- quotas & 2 & - \\
- other & 2 & - \\
Same & $25 \%(4)$ & $33 \%(3)$ \\
- quotas & 1 & 1 \\
Don't know & $12 \%(2)$ & $11 \%(1)$ \\
- it varies & 1 & - \\
- quotas & - & 1 \\
\hline$N_{\text {total }}$ (hunters asked) & 16 & 9
\end{tabular}

Among hunters who responded "same" to question 25, most did not provide an explanation in question 25a. Numbers correspond to the number of hunters who selected each response. Percentages are rounded to nearest integer. See Supplemental Material for full list of interview questions.

TABLE 3 | Distribution of responses to question 26: "What is the means of transport you use nowadays when hunting polar bears?"

\begin{tabular}{lcc}
\hline & Tasiilaq & Ittoqqortoormiit \\
\hline Sledge & $44 \%(7)$ & $78 \%(7)$ \\
Boat & $12 \%(2)$ & - \\
Both & $44 \%(7)$ & $22 \%(2)$ \\
\hline$N_{\text {total }}$ (hunters asked) & 16 & 9 \\
\hline
\end{tabular}

Number in parentheses corresponds to the number of hunters who selected each response. Percentages are rounded to nearest integer. late, later each year and ends sooner than usual, from December to June. We used to go on sledges in October but now we go late December. Soon I will also need to use more boats and sailing for hunting, like many others."

In Tasiilaq $50 \%(n=8)$ of hunters said they travel less than $50 \mathrm{~km}$ away from town to hunt polar bears and $44 \%(n=7)$ reported traveling $\geq 50 \mathrm{~km}$ (range: $15-100 \mathrm{~km}$ ). A few hunters said that "it varies" $(n=2)$. In Ittoqqortoormiit, $67 \%(n=6)$ of the hunters reported traveling less than $50 \mathrm{~km}$, and the remaining $33 \%(n=3)$ travel $\geq 50 \mathrm{~km}$ (range: $14-200 \mathrm{~km}$ ).

In both areas, hunters noted that they now hunt closer to town compared to $10-15$ years ago. In Tasiilaq $40 \%(n=6)$ of the hunters reported hunting closer to town, and another $40 \%$ reported no change (Figure 3). A few hunters $(n=2)$ said they hunt further from town or did not have an opinion $(n=1)$. Four of six Tasiilaq respondents (ca. 67\%) who hunt closer to town attributed this change to less sea ice. The majority $(78 \%, n=7)$ of nine Ittoqqortoormiit interviewees said they hunt closer to town, and most of those hunters attributed this change to loss of sea ice. This change was especially prominent in Ittoqqortoormiit where hunters no longer take extensive dog sledge trips north of the area and instead hunting is focused close to town (Figure 4).

\section{Distribution and Occurrence of Polar Bears}

In Ittoqqortoormiit, hunters provided detailed information about the seasonality of polar bear distribution. Hunters reported that polar bears occur close to town in all seasons, but primarily during the winter months (January-March). According to the hunters, polar bears are present in all seasons at the opening of Scoresby Sound, where the Scoresby Sound Polynya is during winter. The distribution of polar bears during April-June also extends south to the coastal and offshore areas of the Blosseville Coast, and there is a second important area along coast from Traill Island to Sabine Island, extending deep into the fjords to the west. From July to September, when sea ice is at its minimum, polar bears are found along the Greenland Sea coast all the way from Blosseville coast to the southeastern part of Gauss Peninsula, as well as in the Scoresby Sound fjord system. The interviewees indicated that polar bears have the largest range during the months of October-December, occurring basically in all areas between Blosseville Coast and Sabine Island, including several fjord systems (Figure 5). In Tasiilaq, only four hunters described seasonality of polar bears occurrence and data were only provided for the winter and spring. Hunters described bears as being located on glaciers at the end of Sermilik fjord, along the coast north of the Tasiilaq region, including on the ice cap, and in the areas around Skjoldungen. Hunters in both areas also described where they had seen bears on land, including in the mountains or on glaciers. These areas tended to be large and bears were seen locally on multiple glaciers. In Tasiilaq, hunters also described bears as being located on the ice cap and moving across corridors on the ice cap (Figures 6A,B).

\section{Changes in Numbers of Polar Bears}

When asked about changes in the number of polar bears in their hunting areas in the past 10-15 years (since the introduction of the quota), $63 \%$ of hunters in both regions said there are 


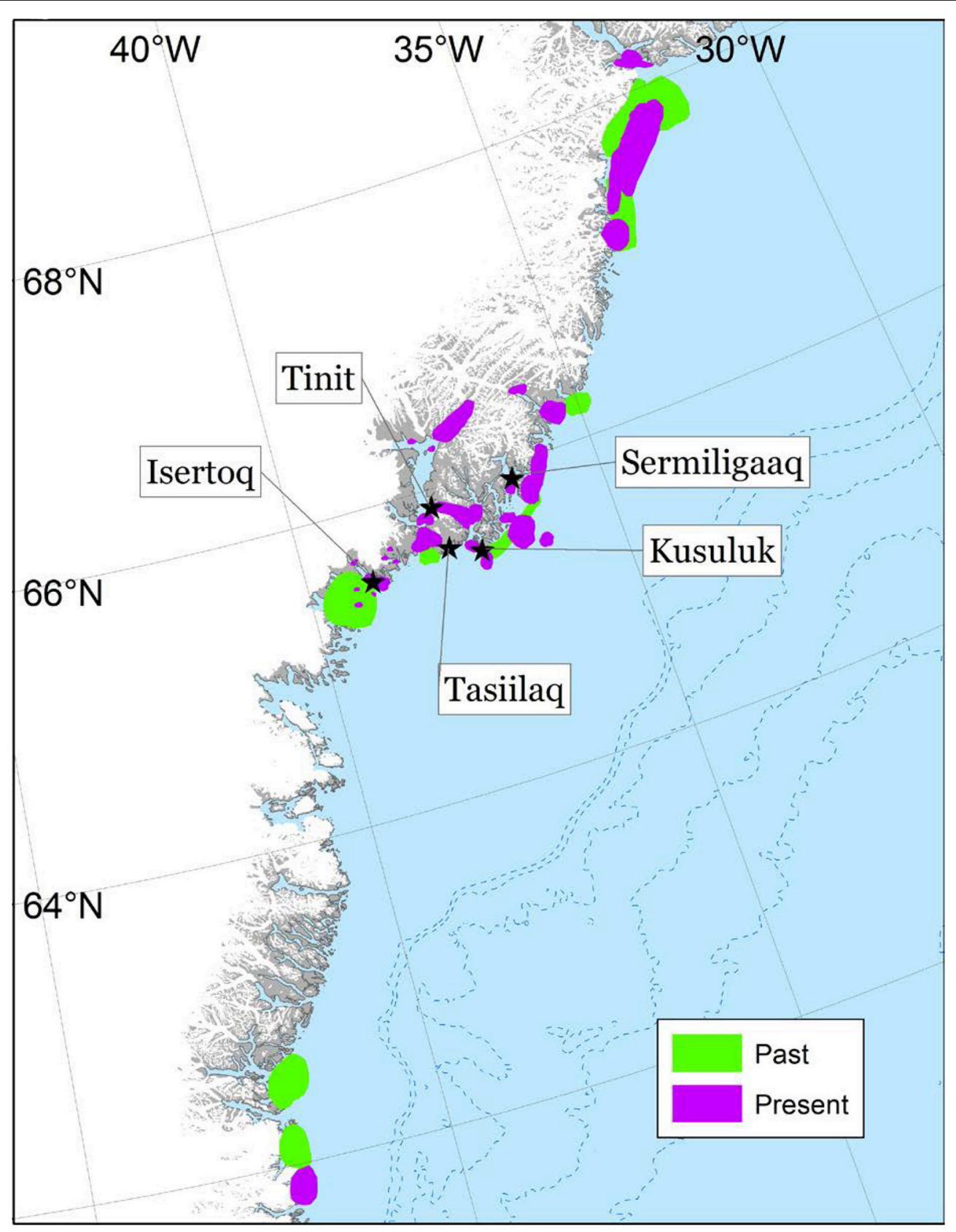

FIGURE 3 | Map of responses from Tasilaq hunters $(n=14)$ showing where they used to hunt bears 10-15 years ago, ("past" in green), and where they hunt bears now ("present" in purple).

"more polar bears." The remaining hunters said they did not know, there was no change, or there were fewer polar bears (Table 4). A variety of responses were given as explanations; the bulk of responses mentioned quotas, sea ice timing, and restrictions on what categories of polar bears hunters are allowed to catch (authors' note: it is forbidden to catch females with cubs, dependent cubs and bears in dens).

About $81 \%(n=13)$ of Tasiilaq hunters also noted that more polar bears are coming into the towns and settlements than
10-15 years ago. Some $(n=3)$ respondents explained that the abundance of polar bears has increased while three other hunters said that the quotas have caused this increase in polar bears around their settlement. A couple of hunters responded that a decrease in sea ice extent has also played a role, with a 38-yearold hunter said "When there was more ice they [the polar bears] were further away, but now there is less ice so they [polar bears] are closer." Two hunters in particular suggested that more polar bears are coming near their town because they are searching for 


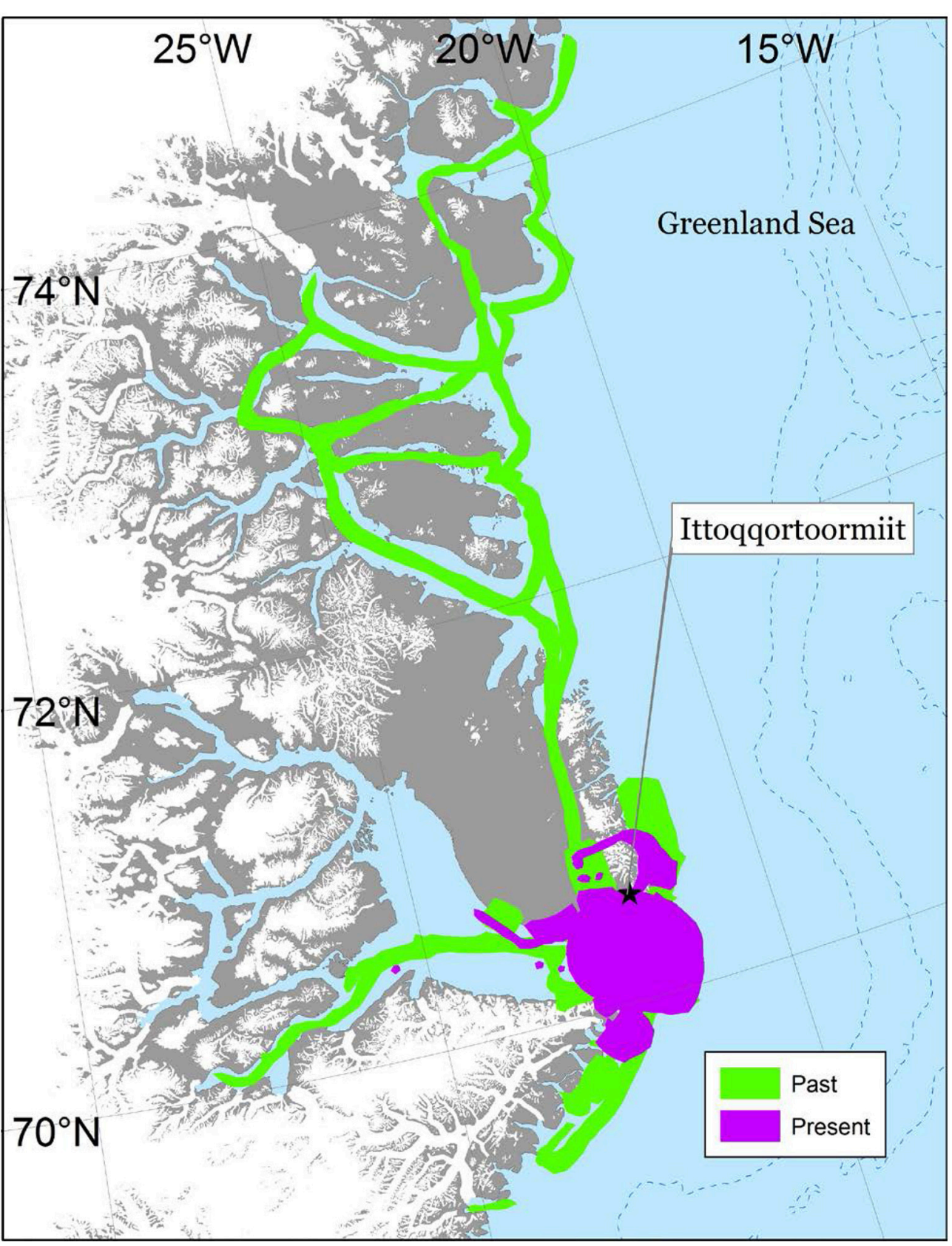

FIGURE 4 | Map of Ittoqqortoormiit responses $(n=8)$ showing where they used to hunt bears 10-15 years ago, ("past" in green), and where they hunt bears now ("present" in purple).

food and have less to eat. About $78 \%$ of the nine Ittoqqortoormiit hunters also said more polar bears are coming to their settlement. Some hunters felt the reasons for this was the introduction of quotas triggering an increase in polar bear abundance. Hunters also mentioned changes in ice.

About $88 \%(n=14)$ of the 16 Tasiilaq hunters said polar bears come close to town sometime within the first 6 months of the year (January-June). Two peaks were recorded, one in the month of January and one in the month of April, with ca.
$69 \%(n=11)$ and ca. $63 \%(n=10)$ of hunters choosing these months, respectively. A variety of responses were recorded; six (38\%) Tasiilaq hunters responded that polar bears come close to town because they are hungry. This is illustrated by the answer of a 34-year-old hunter who said "they [polar bears] come and eat leftovers from dog food [...] they are hungry." Four $(25 \%)$ hunters were of the opinion that ice plays a role in when polar bears come near town. Most of these hunters had selected winter months because of later ice formation, while 


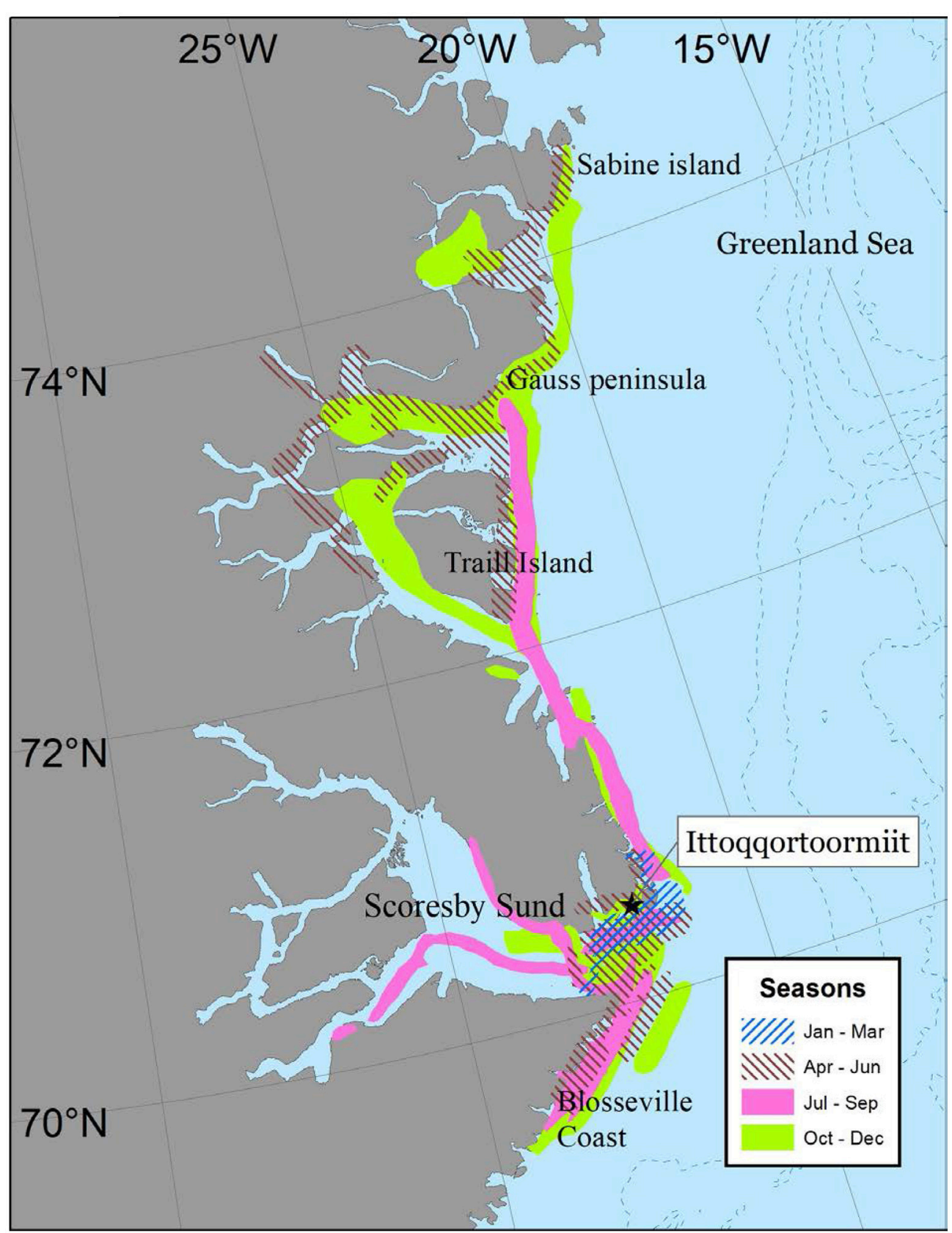

FIGURE 5 | Map of consolidated responses from Ittoqqortoormiit hunters $(n=7)$ illustrating seasonal polar bear distribution.

one hunter explained that many polar bears come around when there is less ice and they are forced on land. Hunters from Ittoqqortoormiit noted that polar bears come close to town in nearly all months of the year. Two peaks of occurrence were recorded in January and July, with $75 \%$ of hunters choosing these months. About 38\% $(n=3)$ of hunters said that polar bears come around late summer because the quotas are used up. Some hunters mentioned ice, e.g., an experienced 56-year-old hunter said, "Because of the new ice conditions [...] the ice disappears and there is a lot less ice, when it finally comes, it disappears with the next storm. The polar bears are on land more because of [...] no ice."

\section{Changes to the Climate}

All 16 informants from Tasiilaq said that they have observed changes to sea ice conditions. About $88 \%(n=14)$ of these hunters explained that there is less ice, the sea ice does not form, or the sea ice is gone. A hunter noted, "They used to go to Kuummiut [from Sermiligaaq] by dog sledge but cannot do that anymore. Now they cannot even go by dog sledge in January 

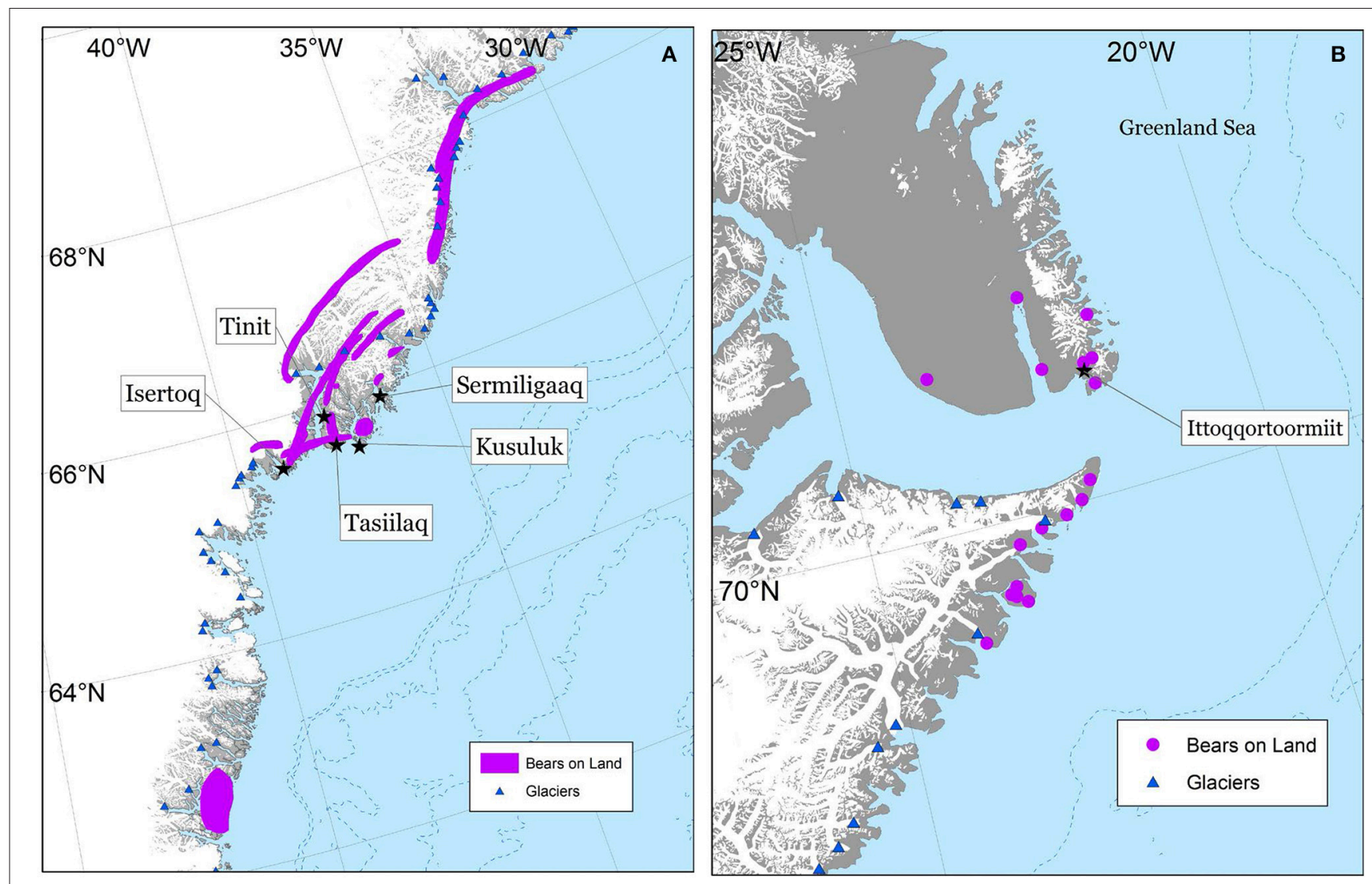

FIGURE 6 | (A,B) Maps of consolidated responses from Tasiilaq hunters $(n=12)$

(A) and Ittoqqortoormiit hunters $(n=7)$ (B) showing where they have observed bears on glaciers, on land, and in the mountains.

TABLE 4 | Distribution of responses to question 34: "Have there been changes in the past 10-15 years in the number of polar bears in areas where you are hunting them?"

\begin{tabular}{lll}
\hline & Tasiilaq & Ittoqqortoormiit \\
\hline Fewer bears & $12 \%(2)$ & - \\
More bears & $63 \%(10)$ & $63 \%(5)$ \\
No change & $12 \%(2)$ & $12 \%(1)$ \\
It varies & $12 \%(2)$ & - \\
Don't know & - & $25 \%(2)$ \\
\hline$N_{\text {total }}$ (hunters asked) & 16 & 8
\end{tabular}

Number in parentheses corresponds to the number of hunters who selected each response. Percentages are rounded to nearest integer.

on the ice [...] the weather is not getting cold anymore and the ice is not coming." Multiple hunters had observed changes in the timing of ice formation, with all describing that the sea ice freezes later. Several hunters reported a shift in the distribution of sea ice, with one hunter who said "places normally having sea ice don't have it anymore," and the other hunter specifically mentioning that sea ice is no longer present in fjords. Two hunters explicitly stated that the sea ice is now more dangerous. Among the nine interviewees from Ittoqqortoormiit, 100\% said they have observed changes to sea ice conditions. Hunters who gave detailed answers stressed that there is less sea ice and more open water, with many of these hunters also noting that the ice edge is getting closer to land and town each year. A few hunters said that the ice does not form or that it is coming later with a shift in distribution. A hunter expressed his surprise at the change in ice distribution, and said "Inside of the fjord [Scoresby Sound] there is almost no ice on the water anymore, it is unbelievable!"

Among 16 Tasiilaq hunters, 94\% $(n=15)$ responded that the glaciers are disappearing, and five hunters stressed that they are disappearing very quickly. One of these hunters said, "When he arrived in 2012 there was much more [glacial ice] and it is disappearing very fast." Many hunters said the glaciers have been decreasing in height, the glacial ice is pulling back, and the ice cap is retreating. An experienced 64-year-old hunter said that he has been able to watch the ice cap retreat just in the last 5 to 10 years. The majority $(67 \%, n=6)$ of nine interviewed Ittoqqortoormiit hunters affirmed that they have observed changes to the glaciers. Among those who elaborated, $100 \%$ stated that the glaciers are getting smaller. One hunter explained that the glacier behind town has gotten very small, and a different hunter predicted that the glaciers will be gone soon. A 56-year-old hunter supplied a personal anecdote illustrating how changes to the glaciers have affected him through his life: "You can really see the difference 
now. Especially when you go across them [glaciers], like on a sledge. There are some places we go across a glacier to come to another place, and the ones behind the town [...] I've used these "roads" all my life and now they are so low and small, you think a lot [about] it each time you cross them [...] some of them disappear completely in the summer and some don't come back anymore." Three Ittoqqortoormiit hunters were unsure or did not have an opinion on the matter.

In Tasiilaq, 69\% $(n=11)$ of the described changes to the snow, while $12 \%(n=2)$ reported no changes, and the rest $(n=3)$ did not have an opinion. Most hunters stressed changes in the amount of snow, though these responses were split between reports of more snow and reports of less snow. Many hunters simultaneously expressed that the amount of snow tends to vary from year to year. A few hunters discussed changes in timing and said that the snow generally comes later. In Ittoqqortoormiit, the slight majority ( $56 \%, n=5$ ) noted changes in the snow while two hunters cited no changes and two said, "don't know." Again, hunters described either more or less snow as further explanation.

Additionally, $100 \%$ of Tasiilaq hunters noted changes in the weather. Generally, hunters from this area experienced worsened weather, warmer temperatures, and more storms and more wind. Many hunters $(38 \%, n=6)$ had observed stronger and more frequent winds. Many hunters added that the bad weather occurs more frequently than it used to and affects the ability to hunt. A hunter who said there are more storms elaborated: "They only had piteraq in the old days but now they also have naqqajaq [...] a different kind of storm" (Authors' note: piteraq means "cold katabatic wind," and naqqaiaq means "northeastern storm"). This response indicated shifts in wind and weather patterns. Three respondents reported that temperatures are warmer than usual, in addition to a hunter who noted weather that is more humid. In Ittoqqortoormiit, $89 \%(n=8)$ of hunters described changes in the weather and roughly $63 \%(n=5)$ of these hunters said the weather is much worse. Hunters cited increased wind, storms, and rain, especially in winter months that used to be good times for hunting polar bears (January and February). About 38\% $(n=3)$ of informants reported warmer weather.

\section{Changes to Polar Bears and Polar Bear Catch With Climate}

Hunters were asked their opinion on whether there had been changes in body condition of the polar bears in their catch. In Tasiilaq, nine hunters (56\%) stated that there has been no change, while $25 \%(n=4)$ said yes, and the remaining $19 \%(n=3)$ said the polar bears vary in condition. The majority of affirmative responses described thinner polar bears. A knowledgeable 63year-old informant reported that there are now more skinny polar bears and said thin polar bears used to be very rare in the past. A man from the same settlement explained that the quotas may have played a role in polar bears becoming thinner, and said "Before the polar bears were very fat, when they had no quotas. Now the polar bears are much thinner." He thinks it is "because there are quotas on them now and there are more polar bears so they get thinner." One other hunter described a change in polar bear behavior and said that he thinks polar bears are generally getting more aggressive because they have less food nowadays.

All hunters $(n=9)$ from Ittoqqortoormiit said there have been no changes in polar bear body condition. One informant explained that there have always been a few thin polar bears. Another 56-year-old informant noted that detecting the changes would be difficult because the quota has influenced when they catch polar bears. He said the reason they have not noticed changes is due to restrictions on the catch of polar bears: "In the time where we could always catch polar bears all year round could we actually see the difference [in condition] between the polar bears, but now we can only catch polar bears in the first months of each year so we don't really have any chance to see the differences."

Hunters were asked how environmental changes impacted the polar bear hunt. Of the 15 Tasiilaq hunters who responded, $73 \%(n=11)$ said changes had impacted the hunt, while $7 \%$ $(n=1)$ said "no" and 20\% $(n=3)$ said "don't know." The majority of responses described how decreased sea ice extent and weather changes have caused more polar bears to occur closer to town. Interviewees also said that it has become more difficult to hunt polar bears because of environmental changes, noting that reduced or no sea ice inhibits hunters from traveling to their preferred hunting areas. One hunter commented: "Because there is no more sea ice we cannot go to some of the regular places to hunt." A few hunters said that their situation has become more difficult. One of these hunters discussed a rather grim future for polar bear hunters: "It has become concerning to be a hunter because the hunters feel like they are in a worse situation. As if they are being abused, there is no future to be a hunter because of the environmental changes."

About $88 \%(n=7)$ of eight Ittoqqortoormiit respondents stated that environmental changes had impacted the polar bear hunt and the remaining hunter did not have an opinion. Many hunters said that hunting locations have changed because of shifts in sea ice and weather conditions. Four hunters in particular mentioned that it is harder to reach their previous hunting areas because the ice has either receded or has become too thin to travel on. A 56-year-old hunter said that he can no longer go over ice to safely hunt in Kape Brewster, which had been possible two years prior. One hunter said "It is hard to reach almost every place now."

\section{Observations on Polar Bear Biology}

Hunters were asked what the polar bears were eating. The majority $(94 \%, n=15)$ of Tasiilaq hunters said they had inspected bear stomachs, as did all nine Ittoqqortoormiit respondents. All hunters cited that polar bears eat the skin and blubber of seals. Many hunters had also observed polar bears eating terrestrial vegetation such as plants, grasses, flowers (e.g., roseroot, Rhodiola rosea), and berries, and a few hunters reported finding seaweed in polar bear stomachs. One hunter also reported polar bears eating eider chicks from the nests and eggs in southeast Greenland.

Some hunters in Tasiilaq had observed changes to what polar bears were eating. One hunter said the polar bears have begun to scavenge more frequently in populated areas, namely near houses and around settlements. Another hunter cited that polar bears are now eating different parts of seals than they used to. He said, "they eat more of it [seals] now. They have started to eat the bones of the 
seal, which they did not do before. Before they only ate the skin and fat." Most hunters in Ittoqqortoormiit had not observed changes in what polar bears were eating, except one hunter who described a polar bear that had been caught with plastic in its stomach.

Hunters were offered the opportunity to state any additional observations or opinions that did not fit into the question scheme. About $44 \%(n=7)$ of Tasiilaq hunters described interesting observations of polar bears. Responses were organized into the following categories: (1) observations about the size of polar bears, (2) accounts of rare and unique morphological characteristics of polar bears, (3) behavioral observations, and (4) other. Multiple hunters provided accounts of polar bears that were particularly large in size. One of these hunters said that in 2012 or 2013 he saw a very big polar bear and stressed that he had never seen such a big polar bear before. A 51-year-old hunter explained that he once caught a very fat polar bear of unknown sex, and added that almost no one could believe how fat it was. This hunter elaborated further and said that the fat on the polar bear was thicker than his hand. A few hunters reported instances of unique polar bear morphologies. A 48-yearold hunter described an interesting skull formation: "a polar bear with a strange growth on the top of the skull... a small piece of bone sticking up on the top of the skull." One informant said that in 2000, he encountered a polar bear that had almost no teeth left because they had been worn down to nubs. A 51-year-old hunter who had seen more than 200 polar bears in his life noted observing a polar bear in the Sermilik glacier climb straight up a vertical piece of glacier ice only using its front legs and claws with its back legs dangling. The hunter expressed how unbelievable it was. Other hunters observed polar bears with one ear, extremely thin polar bears, and those with only 15 claws.

In both areas, several hunters voiced the opinion that only full-time hunters should be allowed to hunt polar bears. Hunters felt it was unfair for those who do not make a living from hunting to be able to take polar bears. Several voiced the opinion that they were looking forward to when there would be an abundance estimate for the East Greenland subpopulation. They also expressed dissatisfaction with not being able to sell their polar bear skins or polar bear parts in the market outside of Greenland (authors note: a voluntary export ban on Greenland polar bear products has been in place since 2008).

\section{DISCUSSION}

This study was initiated, in part, by a lack of information about the East Greenland polar bear subpopulation, especially given the ongoing environmental changes in the Arctic. We were interested in how the polar bear catch has changed since quotas were established in 2006, and how environmental changes have affected the catch and the polar bears in the past 15 years. Hunters provided accounts of a changing physical environment and shifting polar bear distribution, resulting in notable changes to the polar bear subsistence harvest. Striking findings from our study are the overall consensus on climate change and associated environmental changes and the increased incidence of polar bears in or close to settlements. Additionally there has clearly been a shift in the use of hunting areas closer to town, especially in Ittoqqortoormiit.

\section{Quotas}

Quotas are essential in maintaining a well-documented and sustainable subsistence hunt while also allowing for accidental takes in which a polar bear is killed in self-defense. Our study shows that Tasiilaq hunters have an overall positive view of the harvest quota, while Ittoqqortoormiit hunters did not. Quotas restrict the availability of polar bears to full-time hunters only, eliminating competition with leisure (part-time) hunters. A quota benefits hunters in Tasiilaq by reducing competition with part-time hunters, while in Ittoqqortoormiit (where interactions with polar bears are more frequent) a quota limits economic benefit from the hunt.

Mixed responses on how the quota has affected the catch indicate that no marked change has been observed in relation to the quota in both settlements. This may reflect the fact that the quotas were designed to keep catches to a level slightly higher than the average number of catches during the 5 years (20002004) before their introduction. This was done in the absence of scientific advice for the East Greenland subpopulation. There was overall consensus that a hunting officer would help regulate the hunt and could reduce illegal hunting. It was clear from the interviews that hunters are open to sports hunting because of the gain in revenue for the communities. Sport hunting for polar bears is currently illegal in Greenland. The interview also showed that hunters from East Greenland are not selective as to which type of polar bears they hunt; most take the first bear they see when they go hunting, rather than targeting a specific age or size (e.g., large males).

Hunters from Tasilaq mentioned that the traditional rules where the polar bear skin belongs to the first person to see (e.g., observe) the polar bear, rather than the one to shoot it, are problematic and due to this hunters are choosing to hunt alone or with family members. This issue led to action in January 2018 in the settlement of Kuummiut (Tasiilaq) where the local branch of the Association of Fishers and Hunters issued a document stating that the traditional rules for dividing the hunt are no longer valid, and going forward the hunter that shoots the animal will decides about the distribution of the catch (Uitsatikitseq et al., 2018). This applies to polar bears, narwhals and walrus (Odobenus rosmarus rosmarus), species that were previously subject to traditional rules of sharing and are now regulated by quotas.

\section{Environmental Changes}

The physical environment determines the timing of the polar bear hunt and safety of the hunters. There was strong consensus among hunters in both municipalities that negative changes to glaciers, snow, weather, and sea ice had occurred within the last 10-15 years. Specifically that the sea ice forms later and breaks up earlier, and is thinner and less stable. The beginning of this trend was noted in 1999 by East Greenland hunters interviewed by Sandell et al. (2001), based on observations from the 1980s and 1990s. Hunters in the Canada (Nichols et al., 2004; Joint Secretariat, 2015; Laforest et al., 2018) and West Greenland (Born 
et al., 2011) have also made similar observations. It became clear from our study that the amount of snow varies from year to year and trends in snow conditions were difficult to quantify, also reported by hunters in the Canadian Arctic (Joint Secretariat, 2015). Glaciers have retreated in the last $10-15$ years, with many hunters in both settlements expressing concern about the rate at which this was occurring. Hunters in our study and other parts of the Arctic have also noted changes in the weather, noting that the weather has become generally warmer, stormier, and vastly unpredictable (Born et al., 2011; Joint Secretariat, 2015).

\section{Climate Change and Polar Bears}

Our interview survey indicated that polar bear distribution has shifted in recent years and may be related to a decline in sea ice conditions. Most hunters in NW Greenland said that polar bears now occur closer to town (Born et al., 2011), and we documented similar perspectives in this study. It is still unclear whether the observed increase in polar bears near town is because polar bears are being forced onto land with reductions in sea ice, or because there are more polar bears due to the introduction of quotas, or a combination of reasons. The hunters interviewed in this study favored both of these explanations. Alaska Native communities in the northern Bering Sea and Chukchi Sea have also reported changes in local polar bear abundance, though the communities reported varied patterns (Voorhees et al., 2014).

\section{Body Condition}

Generally speaking, Ittoqqortoormiit and Tasiilaq hunters did not report major changes in polar bear body condition, which is in agreement with indigenous informants from the northern Bering Sea, Chukchi Sea, and the western Canadian Arctic and Beaufort Sea regions (Voorhees et al., 2014; Joint Secretariat, 2015). In NW Greenland, 20\% of interviewed hunters expressed that polar bears have become thinner in the North Water region of Melville bay during recent years yet generally did not indicate that there have been widespread changes in body condition (Born et al., 2011). Interestingly, hunters from Tasiilaq reported polar bears consuming more parts of the seals (bones and skin). In both areas, hunters mentioned polar bears come into settlement looking for food, implying a relationship between hungry polar bears and interactions with humans.

\section{Climate Change and the Hunt}

Environmental changes have affected the polar bear hunt within the two areas, as poorer and more unpredictable ice and weather conditions limit hunters' ability to safely travel to hunting grounds. These environmental changes have also affected the polar bear hunt in NW Greenland, as noted by $91 \%$ of interviewed Inuit hunters in the Qaanaaq municipality and the majority of hunters in the Upernavik municipality (Born et al., 2011).

Familiar trails and hunting routes across glaciers have either disappeared, become challenging to find, or too dangerous to use. This has forced hunters to find new hunting routes along outer coastlines that are less ideal because of the reduction in sea ice extent. Glacial retreat has made traveling on dog sledges more dangerous, as also reported by hunters in NW Greenland and Inuit on the Eastern coast of Baffin Island (Dowsley, 2005). An indirect effect of worsened hunting conditions is reduced revenue for hunters, as fewer good hunting days mean a reduced opportunity to catch polar bears and earn an income. These negative effects of climate change were documented during the 1980s and 1990s by Sandell et al. (2001), however are much more pronounced in the present study.

\section{Changes in Hunting Methods}

Within the two East Greenland hunting communities there has been an apparent shift toward the use of boats when hunting polar bears. Hunters in NW Greenland also described an increase in the number of polar bears killed from boats since 1990, mostly due to unsafe and declining sea ice conditions (Born et al., 2011). There is evidence that this shift had begun in Ittoqqortoormiit as early as the 1980s, supported by a marked increase in polar bears killed from boats from the 1980s to mid-1990s (Sandell and Sandell, 1996). The shift to boats during the last 10-15 years could prove dangerous in conjunction with continued decrease in sea ice, as sea ice reduces wave action. Subsistence hunters in northern Alaska have also noted a reduction in safe boating days using small boats and have begun to use larger boats with more fuel-efficient motors to facilitate traveling further offshore (Huntington et al., 2016). Furthermore, boats are more expensive to maintain and could place economic strain on small settlements in Greenland. In Canada, hunters still primarily use snowmobiles and/or dog teams, and shifts in hunting methods have not been recorded (Joint Secretariat, 2015).

Sandell et al. (2001) identified March-June (peak April-May) as the prime hunting period in Ittoqqortoormiit. Responses in this study suggest that the hunting season may have shifted earlier, or January-May (peak February-April). The reason for this shift is unclear, but could be a combination of competition for quotas, shorter trips closer to town (that do not require ideal sledging conditions in late spring), or poorer sea ice conditions in late spring ending the season early. This shift in hunting season was not documented in Tasiilaq.

The hunting locations have also changed. In particular, Ittoqqortoormiit hunters described a marked change in hunting areas compared to 10-15 years ago. Sandell et al. (2001) describe the use of three polar bear hunting areas in Ittoqqortoormiit in 1999: (1) the area north of Scoresby Sound to Danmarkshavn (i.e., mainly inside the National Park of North and Northeast Greenland), (2) the area within Scoresby Sound, including the ice edge along the polynya at the entrance of the fjord, and (3) the area along the Blosseville Coast (Figure 4). Our study confirms that these hunting areas were used in the past, as reported by Sandell et al. (2001), however now only one of those areas is used (area 1-within and around Scoresby Sound). Hunters stated the reason for the reduced hunting range is that there are more polar bears closer to town than before. A similar shift in hunting distribution was documented by hunters in NW Greenland, who said they no longer need to go very far to hunt because the polar bears now occur much closer to town (Born et al., 2011).

In summary, this study provided updated TEK from polar bear subsistence hunters living in East Greenland. These perspectives can be a valuable contribution to the management 
of polar bears in this subpopulation. Collaboration between subsistence users and scientists through the collection of TEK can provide a comprehensive understanding of ecosystems (Ruddle and Davis, 2013; Alessa et al., 2016), especially in the absence of continuous scientific monitoring of the EG polar bear subpopulation. Ambrose et al. (2014) note that combining western science and TEK is useful in the Arctic, where holistic accounts of local climate change can be provided for specific locations. This information can be used to directly guide scientific lines of inquiry, improve management decisions, and overall ensure that TEK is considered in the conservation and management of polar bears, in accordance with recommendations by Vongraven et al. (2012).

\section{AUTHOR CONTRIBUTIONS}

$\mathrm{KL}$ and FU designed the field sampling plans; FU arranged the interviews and collected the data; KL worked with translators to translate the interviews; AN organized and summarized the data into a database. All authors contributed to data analysis and manuscript writing.

\section{REFERENCES}

Alessa, L., Kliskey, A., Gamble, J., Fidel, M., Beaujean, G., and Gosz, J. (2016). The role of Indigenous science and local knowledge in integrated observing systems: moving toward adaptive capacity indices and early warning systems. Sustainabil. Sci. 11, 91-102. doi: 10.1007/s11625-015-0295-7

Ambrose, W. G., Clough, L. M., Johnson, J. C., Greenacre, M., Griffith, D. C., Carroll, M. L., et al. (2014). Interpreting environmental change in coastal Alaska using traditional and scientific ecological knowledge. Front. Mar. Sci. 1:40. doi: 10.3389/fmars.2014.00040

Born, E. W., Heilmann, A., Holm, L. K., and Laidre, K. L. (2011). Polar Bears in Northwest Greenland: An Interview Survey About the Catch and the Climate. Copenhagen: Museum Tusculanum Press.

Dietz, R., Sonne-Hansen, C., Born, E. W., Sandell, H. T., and Sandell, B. (2001). Forekomst af "Afvigende" Isbjørne $i$ Østgrønland: En Interview Undersøgelse 1999. Danmarks Miljøundersøgelser 50s - Faglig rapport fra DMU nr. 359.

Dowsley, M. (2005). Inuit Knowledge Regarding Climate Change and the Baffin Bay Polar Bear Population. Government of Nunavut, Department of Environment. Available online at: https://www.gov.nu.ca/sites/default/files/inuit_knowledge_ regarding_climate_change_and_the_baffin_bay_polar_bear_population. final_wildlife_report_no.1_2005.pdf

Ferguson, M. A. D., and Messier, F. (1997). Collection and analysis of traditional ecological knowledge about a population of Arctic tundra caribou. Arctic 50, 17-28. doi: 10.14430/arctic1087

Fidel, M., Kliskey, A., Alessa, L., and Sutton, O. P. (2014). Walrus harvest locations reflect adaptation: a contribution from a communitybased observation network in the Bering Sea. Polar Geogr. 37, 48-68. doi: 10.1080/1088937X.2013.879613

Huntington, H. P. (1998). Observations on the utility of the semi-directive interview for documenting traditional ecological knowledge. Arctic 51, 237-242.

Huntington, H. P., Quakenbush, L. T., and, Nelson, M. (2017). Evaluating the effects of climate change on indigenous marine mammal hunting in Northern and Western Alaska using traditional knowledge. Front. Mar. Sci. 4:319. doi: 10.3389/fmars.2017.00319

Huntington, H. P., Quakenbush, L. T., and Nelson, M. (2016). Effects of Changing sea ice on marine mammals and subsistence hunters in northern Alaska from traditional knowledge interviews. Biol. Lett. 12:20160198. doi: $10.1098 /$ rsbl.2016.0198

\section{ACKNOWLEDGMENTS}

This study was funded by the DANCEA program from the Danish Ministry of Environment. We thank the interviewers Maja Papé and Lea Madsen, who worked tirelessly to interview hunters. We thank all 25 hunters who contributed to this study for sharing their perspectives. Emma Kristensen, Lene K. Holm, and Anna Heilmann helped to formulate the questions in Greenlandic. Dina Pike and Peter Hegelund assisted with the translations. Richard McGovern assisted with GIS mapping. The Ministry of Fisheries and Hunting of Greenland provided catch data. The Organization of Fishers and Hunters and the Ministry of Fisheries and Hunting provided support and comments during the early stages of this study. Henry Huntington and a second reviewer provided thoughtful comments on the manuscript.

\section{SUPPLEMENTARY MATERIAL}

The Supplementary Material for this article can be found online at: https://www.frontiersin.org/articles/10.3389/fmars. 2018.00135/full\#supplementary-material

Joint Secretariat (2015). Inuvialuit and Nanuq: A Polar Bear Traditional Knowledge Study. Joint Secretariat, Invialuit Settlement Region.

Laforest, B. J., Hébert, J. S., Obbard, M. E., and Thiemann, G. W. (2018). Traditional ecological knowledge of polar bears in the northern eeyou marine region, québec, canada. Arctic 71. doi: 10.14430/arctic4696

Laidre, K. L., Stern, H., Kovacs, K. M., Lowry, L., Moore, S. E., Regehr, E. V., et al. (2015). Arctic marine mammal population status, sea ice habitat loss, and conservation recommendations for the $21^{\text {st }}$ century. Conserv. Biol. 29, 724-737. doi: 10.1111/cobi.12474

Lewis, A. E., Hammill, M. O., Power, M., Doidge, D. W., and Lesage, V. (2009). Movement and aggregation of eastern hudson bay beluga whales (Delphinapterus leucas): a comparison of patterns found through satellite telemetry and nunavik traditional ecological knowledge. Arctic 62, 13-24. doi: 10.14430/arctic109

Nichols, T., Berkes, F., Jolly, D., Snow, N. B., and The Community of Sachs Harbour (NWT). (2004). Climate change and sea ice: local observations from the canadian western arctic. Arctic 57, 68-79. doi: 10.14430/arctic484

Obbard, M. E., Thiemann, G. W., Peacock, E., and DeBruyn, T. D. (eds). (2010). Polar Bears: Proceedings of the 15th Working Meeting of the IUCN/SSC Polar Bear Specialist Group, Copenhagen, Denmark, 29 June-3 July 2009. Gland; Cambridge: IUCN.

Paetkau, D., Amstrup, S. C., Born, E. W., Calvert, W., Derocher, A. E., Garner, G. W., et al. (1999). Genetic structure of the world's polar bear populations. Mol. Ecol. 8, 1571-1584. doi: 10.1046/j.1365-294x.1999.00733.x

Regehr, E. V., Laidre, K. L., Akçakaya, H. R., Amstrup, S. C., Atwood, T. C., Lunn, N. J., et al. (2016). Conservation status of polar bears (Ursus maritimus) in relation to projected sea-ice declines. Biol. Lett. 12:20160556. doi: $10.1098 / \mathrm{rsbl} .2016 .0556$

Rosing-Asvid, A. (2002). The Polar Bear Hunt in Greenland. Technical Report no. 45. Greenland Institute of Natural Resources, Nuuk, 25. Available online at: http://www.natur.gl/en/publications-and-communication/technical-reports/

Ruddle, K., and Davis, A. (2013). Local ecological knowledge (LEK) in interdisciplinary research and application: a critical review. Asian Fish. Sci. 26, 79-100.

Sandell, H., and Sandell, B. (1996). Polar bear hunting and hunters in Ittoqqortoormiit / Scoresbysund, NE Greenland. Arctic Anthropol. 33, 77-93.

Sandell, H. T., Sandell, B., Born, E. W., Dietz, R., and Sonne-Hansen, C. (2001). Isbjørne $i$ Østgrønland. EN Interview Undersøgelse om Forekomst og Fangst, 1999. Technical report nr. 40. Greenland Institute of Natural 
Resources, Nuuk. 94. Available online at: http://www.natur.gl/en/publicationsand-communication/technical-reports/

Stern, H. L., and Laidre, K. L. (2016). Sea-ice indicators of polar bear habitat. Cryosphere 10, 2027-2041. doi: 10.5194/tc-10-202 7-2016

Uitsatikitseq, J., Umerineq, W., Ignatiussen, E., and Pivat, A. (2018). K.A.P.P Piniakkat Killillersukkat Pillugit Ataatsimiinerat. Document issued by the local branch of Kuummmiut, in the area of Tasilaq, of the Organisation of Fishers and Hunters of Greenland. Kuummiut.

Van de Velde, F., Stirling, I., and Richardson, E. (2003). Polar bear (Ursus maritimus) denning in the area of the Simpson Peninsula, Nunavut. Arctic 56, 191-197. doi: 10.14430/arctic615

Vongraven, D., Aars, J., Amstrup, S., Atkinson, S. N., Belikov, S., Born, E. W., et al. (2012). A circumpolar monitoring framework for polar bears. Ursus 23, 1-66. doi: 10.2192/URSUS-D-11-00026.1

Voorhees, H., Sparks, R., Huntington, H. P., and Rhode, K. D. (2014). Traditional Knowledge about Polar Bears (Ursus maritimus) in Northwestern Alaska. Arctic 67, 523-536. doi: 10.14430/arctic4425
Wiig, Ø. (1995). Distribution of polar bears (Ursus maritimus) in the Svalbard area. J. Zool. 237, 515-529. doi: 10.1111/j.1469-7998.1995.tb05012.x

Wong, P. B. Y., Van Coeverden De Groot, P., Fekken, C., Smith, H., Pagès, M., and Boag, P. T. (2011). Interpretations of polar bear (Ursus Maritimus) Tracks by Inuit Hunters: inter-rater Reliability and Inferences Concerning Accuracy. Can. Field Nat. 125, 140-153. doi: 10.22621/cfn.v125i2.1197

Conflict of Interest Statement: The authors declare that the research was conducted in the absence of any commercial or financial relationships that could be construed as a potential conflict of interest.

Copyright (c) 2018 Laidre, Northey and Ugarte. This is an open-access article distributed under the terms of the Creative Commons Attribution License (CC $B Y)$. The use, distribution or reproduction in other forums is permitted, provided the original author(s) and the copyright owner are credited and that the original publication in this journal is cited, in accordance with accepted academic practice. No use, distribution or reproduction is permitted which does not comply with these terms. 